\title{
LONG-TERM UNEMPLOYED SOCIAL BENEFITS RECEIVERS EXPERIENCE TAKING PART IN EDUCATIONAL ACTIVITIES
}

\author{
Anna Bickovska \\ Latvia University of Agriculture, Latvia \\ E-mail: annabickovska@gmail.com
}

\begin{abstract}
Long-term unemployed social benefits receivers are entitled to many educational activities to help them with reemployment in Latvia. Long-term unemployed social benefits receivers attend different educational activities but remain unemployed. It is important to understand why it happens and what kind of additional support longterm unemployed social benefits receivers need. Current research took place in Riga Social Service, long-term unemployed social benefits receivers were interviewed in order to collect data about their experience in adult education and their opinions about the process. The informants were asked to reflect on their future perspective in the aspect of job searching, taking into consideration their freshly obtained education. Interview transcripts were decoded and categorized in 5 distinct categories. Results show that only educational activities can 't solve unemployment problem and employability skills training program should be created.
\end{abstract}

Key words: adult education, career counselling, long-term unemployed, vocational education.

\section{Introduction}

The problem of long-term unemployed social benefits receivers is quite topical in Latvia. Different tools and activities were created to help them, during a couple last years a variety of researches was taking place in Latvia about this target group (Baltic Institute of Social Science, 2015). Most of them conclude that main reasons for being long-term unemployed are the lack of motivation in individuals and the lack of motivational programs for long-term unemployed social benefits receivers. Some researchers have also mentioned problems in social security system residents can receive social benefits for not-limited amount of time as long as they stay unemployed and have no official income (The World Bank, 2013).

Researching long-term unemployed in EU context brings new problems and perspectives. According to the latest researches done in the field long-term unemployed are struggling with adequate skills and education level. In European context, additional complication to the problem is added by raised level of migrant, but it is not yet topical to Latvian labour market (Duell, Thurau, Vetter, 2016).

According to Latvian practice the long-term unemployed social benefit receivers are ablebodied persons who have received monthly benefits for more than 12 times within the last three years and were jobless at least 9 months (SKDS, 2007), and have been receiving social service support at least for the last six months. That is the target group of the research and there is no clear 
statistic data about how many people that fall under these requirements are out of the Latvian labor market now because they tend to get employed for a couple of months or even weeks and then get back to being unemployed again. They attend different adult educational activities when being State Employment Agency's clients, the government spends many financial resources in order to reeducate them, but for majority of them it does not work. While working on her own educational program for adults the researcher wants to find out what are the reasons for staying long-term unemployed from the clients themselves. According to the researcher's previous researches the average long-term unemployed social benefits receiver is a middle-aged person with secondary education and is unemployed approximately for 3 to 4 years in a row (Bičkovska, Pāvulens, 2015).

\section{Problem of Research}

Huge increase in unemployed in Latvia was in 2008 - 2009, when economic crisis took place all over the world. Since then the economic situation in Latvia improved a lot (unemployed rate in Latvia in October 2017 - 6.6\%, comparing to October 2009 - 14.1\%) (Bezdarba limenis valstî, 2017).

Nowadays there are more opportunities to get employed but there are some groups of people who still choose to live on social benefits, not trying to live independent. These people are not separated from the general amount of unemployed, who are becoming those ones and then are getting a job in short period of time. That means that there are no services created for long-term unemployed. All the services (educational as well) they attend are general type of services for unemployed.

It might not be a problem, but already in 1931 M.Jahoda and P.Lazarsfeld doing their research in small Austrian community of unemployed mentioned that long-term unemployment has no financial or developmental impact on individual. Long-term unemployment brings a complex of problems - individual feels lost, not motivated to change, negative and passive (Jahoda, Lazarsfeld, 1976).

That means that long-term unemployed need special services created while also taking into consideration their special needs. As for now there are no such services available in Latvia.

Long-term unemployed social benefits receivers still use what is available at Latvia State Employment Agency, but one of the main limitations is a lack of motivation in long-term unemployed social benefits receivers.

During this research it is hoped to get information on experience of long-term unemployed social benefits receivers of taking part in different educational activities, their opinion on process, methods, usefulness and their expectation towards it.

Latvia State Employment Agency provides a variety of services including an opportunity to reeducate or get additional education. There is a possibility to obtain different types of courses (like drivers, mechanics etc.) and there is an opportunity for those who haven't obtained any specialization yet to get professional education (Nodarbinātības un apmācību iespējas, 2017). There is no clear statistic data available that could show how many of long-term unemployed social benefits receivers who used this opportunity to get professional education or to attend courses have applied it when job searching and are really working in that newly learned field. There is no data that can prove these educational opportunities as useful and widen the field of job searching.

\section{Research Focus}

The current research focuses on trending topics in adult education. Long-term unemployed social benefits receivers are the users of adult education system, so they know best how it works, all the pros and cons.

The main topic of the research was about what changes in methods or process need to be done in order to improve results of long-term unemployed social benefits receivers to become more likely employable. It is important to remember that the goal of attending education activities is not only to get a new specialization but also to acquire new skills and knowledge that are usable in life in order to build strong, independent, working willing personality. 
Baltic Journal of Career Education and Management

\section{Methodology of Research}

\section{General Background}

This research was designed to explore long-term unemployed social benefits receivers' opinion towards their experience with participating in adult education activity. This research uses qualitative approach - data were collected in 10 deep interviews with the long-term unemployed social benefits receivers. The research took place from August 2017 to October 2017.

\section{Sample}

The current empirical research was carried out in Riga Social Service district "Plavnieki". There were 10 long-term unemployed social benefit receivers participating in the research. The participants of the research were as follows: 7 females $(70 \%)$ and 3 males (30\%) between the age of 26 to 57 (Mean $(\mathrm{M})=38.4$, Standard Deviation $(\mathrm{SD})=10.46)$, the age distribution of the respondents is normal (The Shapiro-Wilk W $=.95 ; \mathrm{p}=.12$ The period of unemployment of the respondents vary from 24 to 78 months with average period of unemployment of 40.8 month (or about 3 years and 4 months). In the study sample, statistically important positive correlation exists between the age of unemployed and their duration of unemployment (Spearman's rho $(\mathrm{rSp})=.46, \mathrm{p}=.003$ ), elderly unemployed are longer without a job. In a situation when unemployment rate is $7.5 \%$ (Bezdarba limenis valstī, 2017), which means that it is possible to find a job in relatively short period of time, the long term unemployed prefer to stay unemployed for years.

According to the number or informants it was a pilot research that helped to clarify the structure and topics needed to be worked on in order to complete research in all Riga Social Service districts.

All informants participated voluntary and agreed to the research. All data are presented anonymously.

\section{Instrument and Procedures}

The data were collected between July, 2017 and October, 2017. Each of the informants is a client of the social worker, there was a casework going on with them at the time of the research, all of them used to be users of adult education activities offered by Latvia State Employment Agency or are using them now. They were asked to participate in the interview with the researcher in order to find out about their experience in adult education and their opinions about the process. The informants were asked to reflect on their future perspective in the aspect of job searching, taking into consideration their freshly obtained education.

All informants were instructed by their social worker. The researcher collected the general data - sex, age, level of education and period of unemployment. After that the direct interview questions were asked.

Each interview's length with long-term unemployed was from 1.5 to 2 hours. Each interview was recorded digitally; all information was decoded and categorized in 6 categories:

1. Type of educational activities - respondents explain what kind of educational activities for adults they have attended in order to improve their opportunity to get employed;

2. Results - what does attending of educational activities give them;

3. Process - any ideas and thoughts about the process, how it went, what kind of methods were used;

4. Usefulness - if they have used the knowledge, skills and experience that they have gained during educational activities;

5. Self-confidence - have they gained self-confidence, has it helped them to create a better vision of themselves;

6. Unemployment - respondents' replies why they are still unemployed after so many resources used in resolving their situation. 
The content analysis method was used throughout this research - the main topics of interviews with long-term unemployed social benefits receivers were categorized and coded in order to achieve data that is reasonable for future investigations and can be compared with known theories about adult education.

MS Excel and R 3.2.3 (The R Project, 2016) have been used to process the research data.

\section{Results of Research}

All of the informants attended different types of educational activities (additional education, new qualification etc.), but still remain unemployed. Education of the informants can be described as following - most of them ( $80 \%$ or 8 respondents) have secondary education (it consists of general and professional secondary education); $20 \%$ or 2 informants have graduated from university and have higher education. Distribution differences of the attained educational level among the genders were not statistically significant (Chi-square criterion $\chi^{2}=.27 ; \mathrm{p}=.86$ ).

All of the informants obtained additional courses (Latvian language courses -4 respondents; driving courses (different levels) - 3; foreign language courses (Norwegian - 1, German -2). Six of the respondents have obtained long-term requalification educational program (duration one year or more).

All of the informants mention new experience they got as a result of attending educational activities, asking them to widen the meaning of it - new skills (ability to drive a lorry; ability to speak foreign language;), new acquaintance (all of the respondents have mentioned it as an advantage of attending educational activities).

"It was great to have a schedule for two months while I was attending classes [Latvian language courses], I have met two nice women, with whom we are chatting sometimes on the phone, they are unemployed for a very long period as well." (Woman, 43 years)

None of the informants has mentioned anything related to job searching - invitation to job interview, new job etc. None of them has mentioned any kinds of reflection on themselves as an advantage or new ideas of how to organize their future in order to improve their social situation. Some of them are hoping for some traditional ways of getting employed (with the help of friends), but are not relying on their newly obtained education/qualification.

"Interviewer: Do you hope to find a job after attending courses?"

Men: Well, you see, no one really is interested in my diploma. All of them [employers] are looking for experience, but I was having different problems for 4 years and wasn't able to work. Maybe some of my friends will be able to help me.

Interviewer: Are your friend employed?

Man: Some of them - yes, but they are busy. I connect with unemployed ones more often.

Interviewer: How will they help you to find a job?

Man: Silence, no answer. "(Man, 52 years old)

All of the informants mentioned that attendance of the courses/educational program was mandatory. As well as all of them mentioned that educational process was mostly held by the teacher information and tasks were given, and they were asked to listen, to complete the tasks and later check it together in the group, sometimes homework was given too. 
Baltic Journal of Career Education and Management

"Each time you enter the class you need to sign the attendance paper, if you missed a class at least twice they will evaluate if you are eligible for monthly scholarship [some of the courses at Latvia State Employment Agency are "paid" - unemployed get monthly scholarship 100 EUR]. There was one woman who missed 4 times during the month and they haven 't paid her. I needed money, so I went to all of the classes." (Woman, 39 years old).

All of the informants mentioned that they got useful information during courses/educational programs, but none of them was able to mention a real situation where they would be using new information, skills, knowledge.

"It was useful to get knowledge on how to drive a truck, I have a certificate now. Five months passed since then, but no one invited me to job interview. I'm afraid that if I got invitation to interview and they will ask me to drive I won't be able to do so." (Man, 41 years old)

Only two of the informants have mentioned that they gained self-confidence, other respondents mentioned, that they need to improve their level of self-confidence, but they are not sure how they can do it or is it even possible for them.

"You know, I've been attending different courses for more than 4 years. And what? I'm still unemployed, I hate going there, but I need to. Other people [participants of the courses] are so negative; they always blame the government, society and what else as the cause of their problems. I mean, I know that I don't look good, that I'm quite old, I don't have proper education, but I want something bright in my life. I don't know how to get it. No one really cares about me and my feelings". (Woman, 54 years old).

One informant while delving more deeply into this topic mentioned that it is impossible to raise self-confidence attending courses available at Latvia State Employment Agency, because this organization is a bureaucratic tool to manage the level of unemployment in the country.

"They [teachers] don't really care about us, they don't really consider that we can get something useful from that education. That is just their business, they get money from government and pretend that they are teaching us, but none of them cares how we got the material or is it possible to use it now. This is just a machine that needs us to move forward and to show Europe that we [country Latvia] are teaching our unemployed." (Man, 52 years old).

Three out of ten informants mentioned that they were invited to job interviews, but were rejected at the end because of the lack of experience (respondents attended driving courses), one of the respondents has found a job after attending driving courses and getting a new driving license, but was fired from the job after two months (the reason wasn't mentioned), the rest of the informants mentioned that labour market needs real experience, but not certificates, so employers are interested in potential workers' real skills, but not papers.

"I have a babysitter's certificate, I have the Latvian language certificate, and I have a landscape designing certificate. So what? I'm unemployed. If you want to work as a babysitter, they want to call your previous employer and ask questions. If you want to be a landscape designer, they ask you to show portfolio. All these courses are created only for money making, not for people's needs." (Woman, 39 years old)

\section{Discussion}

Long-term unemployed social benefits receivers is not the easiest target group for obtaining education because of the negative experience they have got during the time of being unemployed and socially inactive. As Paulo Freiro mentioned in his work "Pedagogy of oppressed" (1970), traditional pedagogy as "banking model" (Freire, 2007), it is exactly what respondents have mentioned describing their experience in attending different education activities while being adult - teachers/ 
lecturers are giving them material they need to work with. Even the process itself can be mentally rejected by an average adult, because for some individuals it might be hard to accept that someone

knows better and is going "to teach" them. Long-term unemployed social benefits receivers are not the exact target group Paulo Freiro was working with, but they are also in some way "oppressed" by society as well.

They are oppressed by the social security system - it allows receiving social benefits for enormous amount of time. There is no time limit or money limit, as long as a person is a registered unemployed and has no income - he or she can receive social benefits (Sociālo pakalpojumu un ..., 2002), but the best motivation is need - when a person needs food, shelter it motivates the person to move forward. Living on benefits allows a person to be safe, have food, a place to live and do nothing.

Democratic, European context cannot allow us to leave huge number of people without the basic needs being provided; otherwise, they will start to fight for their rights and needs. Society provides them with different types of development services (therapy, social worker counselling, career counsellor service, re-education, additional certification and professions). State Employment Agency provides more than 30 different activities for long-term unemployed with different problems (addictions, health issues, disabilities, youth etc.) (Nodarbinātības un apmācības iespējas, 2017). All long-term unemployed are using some kind of these activities, especially, educational possibilities, but rarely some of them are employed because of it.

Additional education or reeducation is effective in case of short-term unemployment when a person still remembers how it is to be working all day long, earning money, providing for family, being an active member of society when the mind is still clear and said person wants to change and move forward.

In case of long-term unemployment that is not working anymore, even in classical lifelong education principle - lifelong education is based on inner motivation to get new skills and knowledge, to broaden personality (Skujiņa, Belickis, 2000). Because of the changes in their personality, long-term unemployed during the years of being unemployed and living on social benefits are not willing to educate themselves and accept the idea of education through the whole life in all fields of life (Memorandum on Lifelong Learning, 2000).

Swedish experience contributes to that idea as well - long-term unemployed who completed at least two levels of comprehensive secondary education have higher level of employability in the future (Stenberg, Westerlund, 2008).

According to the research "Discrimination in Latvian labor market" (2014) potential long-term unemployed are more likely youth (up to 24 years old) (without proper education or without any education); pre-retirement aged people (from 50-64) (more often their education needs approval or some additional training due to new technologies, they are less likely active in adult education field and more negative about it); people with disabilities (often due to their disabilities education is not provided for them and they are not able to work even in the field, it would be impossible due to their health issues); people with weak knowledge of Latvian (due to Latvian history there are a lot of Russian speaking people who are not able to speak Latvian properly, every Russian speaking individual (if higher education is not obtained in Latvian) needs to present a certificate of Latvian language knowledge degree (different categories) in order to get employed); women after maternity leave (up to 1,5 women can stay at home on maternity leave, after 1,5 they need to come back into labor market, but there is a very huge problem with pre-school, woman rarely gets a place for her 1,5 years old kid, so she needs to stay at home longer and it might become a problem in a perspective) (Discrimination in ..., 2014).

The aim of government and local authorities in creating different educational opportunities is to help long-term unemployed become employed, to start living independently, to grow the income of the family, so the person would be able to pay taxes and bring benefits to the society by working. In this process, not only education itself is important, it is important to raise long-term unemployed employability. As it might be seen from the results, long-term unemployed attends different courses and educational program but the result is not achieved. Additional training should be done in order to raise long-term unemployed self-confidence, motivation, ability to promote themselves during job interviews. 
Baltic Journal of Career Education and Management

28

Dutch experience shows that employability, even among long-term unemployed social benefits receivers, can raise the chance of reemployment (Koen, Klehe, Vianen, 2013). Employability is a complex of skills that should help individual get employed. This set of skills varies from author to author, but it mostly includes communication, team work, leadership, initiative, problem-solving, flexibility and enthusiasm (Fugate, et.al., 2004).

This should be the main topic for creating new services and training for long-term unemployed. Latvian State Employment Agency was trying for years to educate long-term unemployed to help them get employed but it wasn't successful. It is time to try innovative approach and invest in personal development and not in getting additional certificates.

\section{Conclusions}

Existing system of services for long-term unemployed includes different type of educational activities, but in most of the cases it does not help long-term unemployed get reemployed.

According to the interviews, long-term unemployed social benefits receivers are mostly sceptic about their future, they do not feel any interest in it and consider provided educational activities as formal thing.

As one of the suitable way of solving existing problem - employability training should be invented. Employability training should consist of training individual features of long-term unemployed, using their existing experience and knowledge.

Only open-minded, active, positive, well-skilled individuals can truly attend educational activities, get positive experience and use new skills to get reemployed.

\section{References}

Baltic Institute of Social Science (2015). Pētījums par administratīvā sloga samazināšanas iespējām un inovatīvām pieejām ilgstošā bezdarba problēmu risināšanā [Research on decreasing administrative costs and innovative opportunities in solving long-term unemployement problem]. Rīga, pp.91. Retrieved from November 27, 2017 http://www.mk.gov.lv/sites/default/files/editor/4._gala_zinojums_29.07.2015.pdf.

Bičkovska, A. Pāvulens, J. (2015) Support in the job search for long term unemployed social benefit receivers. Proceedings of the 22d International Conference Research for Rural Development 2016. Retrieved from October 17, 2017 http://www2.1lu.lv/research_conf/proceedings2016_vol_2/docs/ LatviaResRuralDev 22nd vol2-254-259.pdf

Duell, N., Thurau, L., Vetter, T. (2016). Long-term unemployment in the EU: Trends and policies. Retrieved from November 27, 2017 https://www.bertelsmann-stiftung.de/fileadmin/files/user_upload/Studie_NW_ Long-term_unemployment.pdf.

Freire, P. (2007). Pedagogy of the oppressed. New York: Continuum.

Fugate, M., Kinicki, A.J., Ashforth, B.E. (2004). Employability: A psycho-social construct, its dimensions, and applications. Journal of Vocational Behavior, 65, 14-38 Retrieved from November 27, $2017 \mathrm{http}: / /$ www.sciencedirect.com/science/article/pii/S0001879103001611?via\%3Dihub.

Koen, J., Klehe, U-C., Vianen, E.M. (2013). Employability among the long-term unemployed: A futile quest or worth the effort? Journal of Vocational Behavior, 82, 37-48. Retrieved from November 27, $2007 \mathrm{http}: /$ www.sciencedirect.com.ezproxy.llu.lv/science/article/pii/S0001879112001418.

Memorandum on Lifelong Learning. (2000) Retrieved from October 16, 2017: http://www.bologna-berlin2003. de/pdf/MemorandumEng.pdf.

Jahoda, M., Lazarsfeld, P. (1976). Marienthal: The sociography of an unemployed community. New York: Transaction Publishers.

Projektu kvalitāte un vadība (2014). Diskriminācija Latvijas darba tirgū [Discrimination in Latvian labor market]. Retrieved from October 16, $2017 \mathrm{http} / /$ www.nva.gov.lv/docs/30 53217f16241943.63850296.pdf.

Saeima (2002). Sociālo pakalpojumu un sociālās palīdzības likums [Law on social help and social service]. Retrieved October from 16, 2017: http://likumi.lv/doc.php?id=68488. 
SKDS (2007). Pētījums par ilgstošo sociālās palīdzības sañēmēju - bezdarbnieku iespējām darba tirgū Rìgas pilsèt $\bar{a}$ [Research on opportunities in labour market of long-term unemployed social benefits receivers in Riga]. Rīgas Domes Labklajības Departaments: Rīga, 91 lpp. Retrieved from October 16, 2017: http:// www.sus.lv/en/node/3003.

Skujiņa V., Belickis I. (2000). Pedagoǵijas terminu skaidrojošă vārdnīca [Dictionary of pedagogic definitions]. Rīga, Zvaigzne ABC, 248 pp.

Stenberg, A., Westerlond, O. (2008). Does comprehensive education work for the long-term unemployed? La-

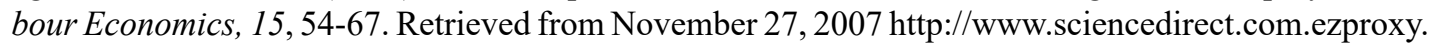
llu.lv/science/article/pii/S0927537106000935.

The R Foundation (2016, February). The R project for statistical computing. Retrieved from October 16, 2017 http://www.R-project.org/.

The world Bank (2013). Scientific research: Latvia: "Who is unemployed, inactive or needy? Assessing postcrisis policy options". Retrieved from November 27, 2017 http://www.lm.gov.lv/upload/aktualitates/ lv_profiling_270513.pdf.

Valsts Nodarbinātības Aǵentrūra [State Employment Agency] (2017). Nodarbinātības un apmācību iespējas [Employment and education opportunities]. Retrieved from October 17, $2017 \mathrm{http} / / /$ nva.gov.lv/index. php?cid= $433 \&$ mid $=311 \&$ txt $=2903 \&$ from $=0$.

Valsts Nodarbinātîbas Aǵentrūra [State Employment Agency] (2017) Bezdarba līmenis valstī [Unemployment rate in Latvia] Retrieved from October 17, 2017 http://nva.gov.lv/index.php?cid=6\#bezdarbs

Received: November 11, 2017

Accepted: December 28, 2017

Anna Bickovska Mg.ed., PhD Student, Latvia University of Agriculture, Lielā iela 2, Jelgava, Latvia.

E-mail: annabickovska@gmail.com 